\title{
Estudio interdisciplinario y experiencia educativa sobre la alimentación Mocoví
}

Benzi, Marina; ${ }^{1}$ Wicky, Mariel; Camargo, Ana; ${ }^{2}$

Recibido: 22/09/2016

Escobar, Yamila

Aprobado: 21/11/2016

\section{Resumen}

En el presente trabajo se pretende destacar tres acontecimientos que merecen ser conocidos y difundidos. Los mismos tuvieron lugar en la carrera de Lic. en Nutrición, FBCB, de la UNL. En primer lugar, la realización de la tesina de las licenciadas en Nutrición, Ana L. Camargo y Yamila A. Escobar sobre los hábitos alimentarios y de consumo en la población Mocoví Aim Mokoilek de Colonia Dolores, los cambios en las últimas décadas y relación con el estado nutricional actual. Por otro lado, en el transcurso del dictado de la materia de Socioantropología de la Alimentación del 2016, Ana Camargo ofrece una clase expositiva sobre el trabajo de investigación, la cual aborda la cuestión alimentaria desde una mirada interdisciplinaria, y comparte con el alumnado su aprendizaje y vivencia respecto a cuestiones teóricas-metodológicas específicas de su proyecto. Para finalizar, es meritorio reflexionar el lugar de Ana Camargo desde la cuestión metodológica, ya que al pertenecer a la comunidad mocoví de Colonia Dolores, su rol como investigadora debe ser problematizado. Los sucesos imprimen en la formación de los docentes y el alumnado, un compromiso humanitario; por lo tanto, se logra rescatar valores y formas de vida de la comunidad mocoví en y desde el ámbito universitario.

Palabras clave: hábitos alimentarios, pueblo mocoví, abordaje interdisciplinario, experiencia educativa, extrañamiento.

\footnotetext{
${ }^{1}$ Benzi y Wicky.FByCB -UNL. Paraje El Pozo.Santa Fe, Santa Fe. Argentina. Dirección Postal: Maipú 1557. Teléfono: 0342- 4535104. marinabenzi@yahoo.com.ar.

${ }^{2}$ Colonia Dolores, Santa Fe. Argentina. Dirección Postal: calle s/n Zona Urbana. Teléfono: 03498 - 15401675. lic.anacamargo@gmail.com
} 


\section{Summary}

They took place in the race Lic. in Nutrition, FBCB, UNL. On the one hand, the realization of the thesis of graduates in Nutrition, Ana L. Camargo and Yamila A. Escobar on eating habits and consumption in the Aim Mokoilek Mocoví population of Colonia Dolores, changes in recent decades and relationship to the state current nutrition.On the other hand, during the dictation of matter of Socio-anthropology of Food 2016, Ana Camargo offers an expository lecture on the research, which addresses the food issue from an interdisciplinary perspective, and share with students their learning and experience regarding theoretical and methodological issues specific to your project. Finally, it is meritorious to reflect on the place of Ana Camargo from the methodological question, since to belong to the community mocoví of Colonia Dolores, her role as a researcher must be problematized. The events printed on the training of teachers and students, a humanitarian commitment; therefore, it manages to rescue values and ways of life of the community mocoví and from the university.

Keywords: eating habits, mocoví people, interdisciplinary approach, educational experience, estrangement. 